\title{
Trail management, off-trail walking and visitor impact in the Pieniny Mts National Park (Polish Carpathians)
}

\author{
Anna Kolasinska, Paweł Adamski, Szymon Ciapała, Juraj Svajda \& Zbigniew Witkowski
}

Keywords: off-trail walking, technical motives, volitional motives, trail design, visitor impact, Pieniny Mts National Park (PNP)

\section{Abstract}

The objective of this study was to determine the numbers and percentages of various groups of visitors hiking off trail, the motives driving visitors to do so and the damaging impact on nature and the environment. Sections of eight routes in the Pieniny Mts. National Park (NP) were selected for the study. On average, $29.4 \%$ of visitors were found to have strayed from the official routes, with children being the most prominent group (38.2\%). The groups led by guides left the trails significantly less than other groups ( $24.2 \%$ and $30.5 \%$ respectively). Technical reasons for leaving a trail, e.g. crowds or obstacles on the route, predominated over volitional reasons, such as taking photographs or resting (56.8\% and $43.2 \%$ respectively).

The proportion of persons walking off route drops significantly when the route has kerbs $(Z=2.10638 ; p=0.0352)$, and a convenient trail surface (7.06311; $p<0.0001)$. Additionally, a negative correlation was found between walking off the route and the mean $(\rho=-0.2048 ; p=0.0018)$ and minimum width of the route $(\rho=-0.3244 ; p<0.0001)$.

A significant correlation was found between the type of habitat surrounding the route and the damaged surface $(H=37.4932 ; d f=2 ; p<0.0001)$. In forest habitats, the breadth of the zone where vegetation was completely absent was significantly larger than in mixed habitats $(Z=5.35021 ; p<0.0001)$, and non-forest habitats $(Z=5.35331 ; p<0.0001)$. Similarly, in forest habitats the surface of the zone with damaged vegetation was significantly larger than in the remaining habitats $(H=154.7565 ; d f=2 ; p<0.0001)$. The total length of informal trails branching off from the study areas was $242 \mathrm{~m}$, which constituted $63 \%$ of total length of the stages of the studied routes.
Profile

Protected area

Pieniny Mts National

Park

Mountain range

\section{Carpathians}

Country

Poland

\section{Introduction}

In the prevailing social consciousness national parks are the most recognizable form of nature protection (Bushell et al. 2007; Manning \& Anderson 2012). Two of the most important functions of these areas include, on the one hand, the protection of the quality and integrity of the system, resources and formations of nature, and, on the other, the provision of visitor access to the national park. Of these functions, even though they are treated equally in the classification of the global conservation organization, the International Union for Conservation of Nature - IUCN (Eagles \& McCool 2002; Dudley 2008), in the majority of countries it is the function of protecting nature that is given priority above the function of making the park available to visitors (Mappes 2007).

The management of tourism in protected areas concurrent with the preservation of the natural heritage is an extremely difficult task to implement and still constitutes a significant challenge (McCool 2009; Manning 2011). Hiking beyond the marked routes by tourists, which is a direct factor in creating informal trails, is the single most important reason for the damage and destruction caused in protected areas (Cole
2004; Bacon et al. 2006; Kim \& Daigle 2011). In the present study this element is a central link in the chain of relationships combining the preparation of trails and their surroundings with the natural and environmental consequences associated with off-trail walking. In topical publications two such factors are indicated: preparation of the trail (Park et al. 2008; Olive \& Marion 2009; Walden-Schreiner \& Leung 2013), and the knowledge, level of education and experience of visitors to these protected areas (Freimund \& Cole 2001; Leung et al. 2001; Lynn \& Brown 2003; Park et al. 2008).

The publications discussing the preparation of trails and their surroundings for visitors (Buckley 1999; Eagles \& McCool 2002; Manning 2011; Newsome et al. 2012) emphasize the need for proper infrastructure, including viewing platforms, barriers and toilets, as well as careful planning of the network of trails and roads (Orams 1996; Kuo 2002; Manning 2011). A experiment made on a heavily frequented tourist trail, on Cadillac Mountain in Acadia National Park (Park et al. 2008), confirmed that the best methods for preventing tourists from straying from marked trails are the technical methods of preparing routes and their surroundings (i.e. direct management), whereas the methods affecting the attitudes and knowledge of visi- 


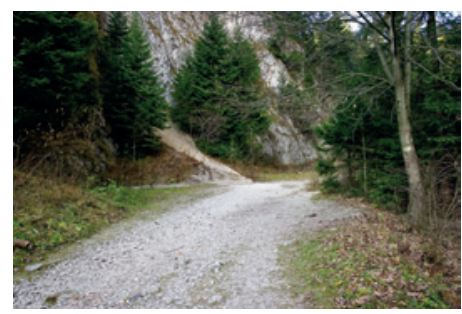

Area No. 1

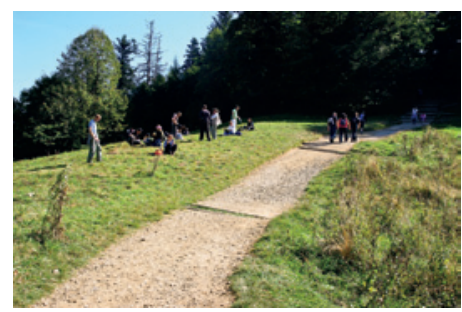

Area No. 4

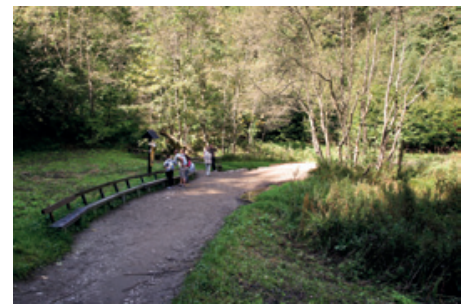

Area No. 6

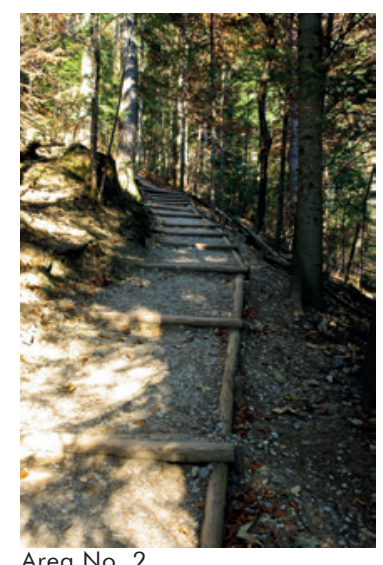

Area No. 2

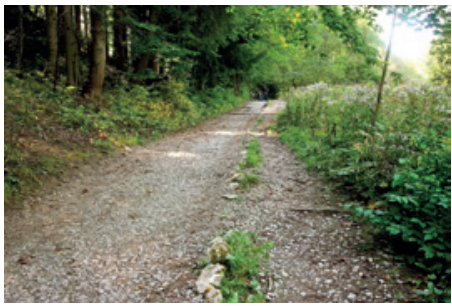

Area No. 7

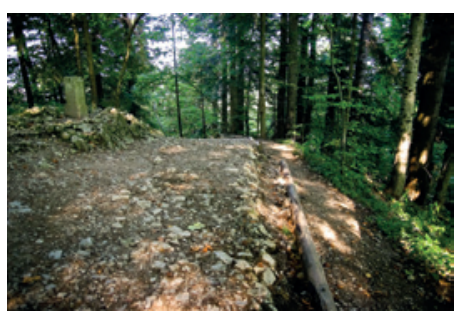

Area No. 3

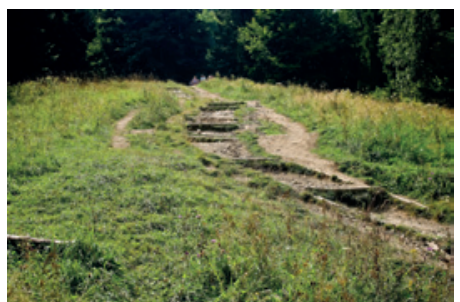

Area No. 5

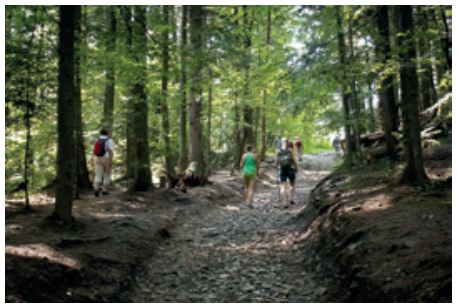

Area No. 8

Figure 1 - Situation of the study areas in Pieniny Mts National Park. Numbers 1-8 designate individual study areas. (C) Anna Kolasinska

tors (i. e. indirect management) were deemed to be the least effective.

The last stage of the relationship discussed here involves the natural and environmental effects of walking off-trail. The majority of studies concerning the impact of visitors on the trails focus on the changes in soils and in the micro-relief of the areas close to the trails, as well as on the destruction of the ground cover (Guzikowa 1982; Hammitt \& Cole 1998; Deng et al. 2003; Cole 2004; Monz et al. 2010; Pickering et al. 2010). Also studied were social and parallel trails (Bacon et al. 2006; Kim \& Daigle 2011; Leung et al. 2011; Wimpey \& Marion 2011; Walden-Schreiner \& Leung 2013), as well as the trampled surfaces, waste and faeces (Poleno 1998; Witkowska-Żuk 2000; Bazyly et al. 2003; Budruk \& Manning 2006).

In Pieniny Mts. National Park (PNP), one of the smallest and most heavily visited national parks in Poland (Partyka 2010a, 2010b), it is imperative that the tourists remain on the marked trails. However, even cursory observations reveal damage around the trails caused by improper behaviour by tourists (Witkowski et al. 2010). The management of tourist traffic in PNP consists of three elements:

1. The measures conceived as soft (Manson 2005) or indirect (Park et al. 2008) management. These include actions undertaken by the park services directed at developing awareness and broadening the knowledge of visitors (e.g. exhibitions, leaflets, folders presented in the park information centres, information embedded in the website of the park (www.pieninypn.pl), information boards along the trails, training of guides, and educational materials (directed chiefly at local communities) (Kolasińska 2014).

2. The measures including both soft (indirect) and hard (Manson 2005) or direct (Park et al. 2008) management practices. These include preparing the trails so as to facilitate the free movement of visitors, establishing suitable resting places and providing the trails with the necessary infrastructure to prevent uncontrolled off-trail walking (e. g. barriers, railings, kerbs, protective board walks) (Adamski et al. 2013). Also included could be the preparation of trail surroundings, allowing for rational and controlled use of natural and landscape resources in the vicinity of the trails.

3. Measures of the hard (direct) type of management, which forces visitors to stay on marked trails. This requires the drafting of suitable legal regulations and their enforcement by cautioning visitors who walk off-trail, as well as punishing those who persistently or carelessly disobey the regulations (Adamski et al. 2013; Kolasińska 2014).

The presented study focused on the second of the above systems of tourist movement management in PNP.

The objective of the study was organized in the following sequence:

1. The first component of the study objective was trail management as it is broadly understood. The 


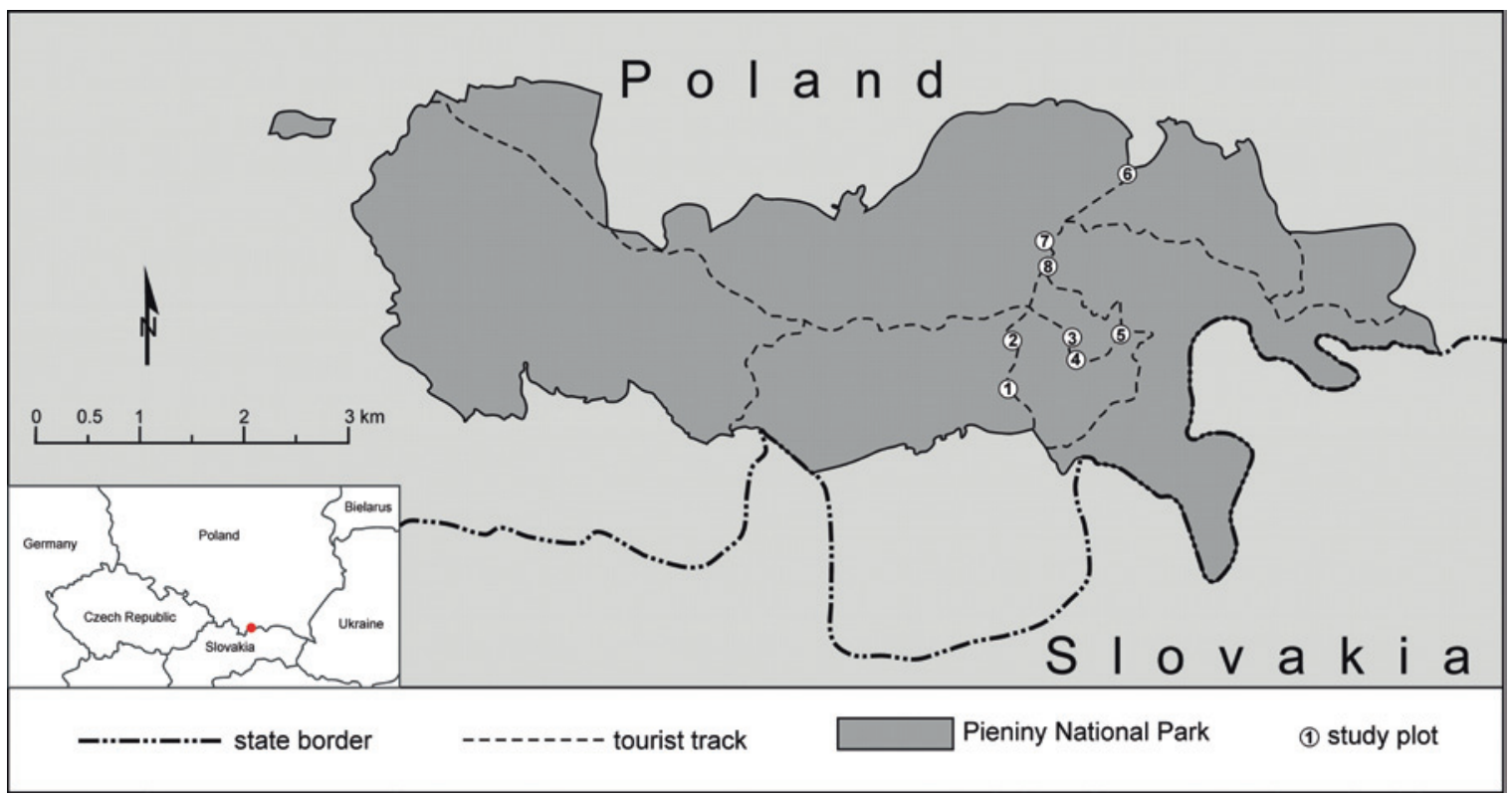

Figure 2 - Study areas

width of the trail and composition of habitats in its surroundings were studied, together with the elements of trail infrastructure affecting the level of off-trail hiking. The latter covered the surface of trails, presence of wooden kerbs and elements preventing walkers from straying from the trails (e.g. railings, barriers and protective boardwalks), as well as the existence of marked resting places on or near the tourist routes.

2. The next component of the study objective was the estimate of numbers and proportions of persons walking off-trail. The analysis was carried out separately for four age groups and for the visitors using or not using the service of a professional guide.

3. Determining the reasons why visitors walked off-trail. Based on the studies available to date (Gmyrek-Gołą et al. 2005; Adamski et al. 2013; Kolasińska 2014), we distinguished two groups of reasons (treated in detail in the Methods section): volitional reasons and technical reasons.

4. To complete the study of the chain of relationships we analysed the types and scope of damage exerted by visitors walking off the trails. This included an assessment of trampled zones and areas with destroyed ground cover around the trails, as well as an inventory of informal paths and places where people relieve themselves.

In the above-presented chain of relationships it was presumed that trail preparation has a significant effect of the level of tourists walking off-trail and that the number of visitors present outside trails significantly affects the size of trampled zones and the zones with damaged ground cover.

\section{Study area and methods}

\section{Study area}

PNP was established in 1932. It is situated in the Carpathians and covers an area of 2374.36 hectares. The most characteristic element of its land relief is the Dunajec River Gorge, and the highest summit within the park is Mount Trzy Korony (982 $\mathrm{m}$ a.s.l.). A unique mosaic of landscapes (Zarzycki 1982) and habitats (Kaźmierczakowa 2004) supporting an unusual abundance of fauna and flora (Razowski 2000; Witkowski 2003) is the remarkable feature of the park.

Within the park area there are three types of trails adapted to different kinds of activities: the water route along the Dunajec River, biking trails and walking trails. The walking trails dominate with a total length of $27.2 \mathrm{~km}$, a density of $15 \mathrm{~m}$ of trails per hectare (Dziadon et al. 2006) and are the highest among the Polish national parks. At many stages of the trails, the permissible daily tourist capacity is consistently exceeded (Celichowski 1977; Warcholik 2010). PNP is one of the three most popular national parks for tourists in Poland (Partyka 2010b) and visited by over 700000 people each year (Partyka 2010b).

Eight short sections of various trails, situated on the most popular and heavily frequented (Kiszka 2010) routes leading to the highest summit in the park from nearby localities, were selected as study areas (Figure 1, Figure 2). They were the most representative in terms of landscape and - at the same time - comparably loaded with tourist traffic. Their geographical coordinates were determined using GPS measurements. Because of the limited field of observation of researchers counting visitors walking beyond the trails, the length of the studied trail sections ranged from $33 \mathrm{~m}$ to $75 \mathrm{~m}$. The sections regarded as study areas were designated a number ranging from 1 to 8 (Figure 1). 


\section{Methods}

The studies were made during the period from 2009-2012, with the exception of 2010, which experienced highly unusual weather conditions (heavy rains and local inundations). Each year the studies were performed from May to September.

In order to estimate the level and reasons causing people to leave the trail at selected sections, direct observations were carried out, as is commonplace in monitoring studies (Hendee et al. 1990; Watson et al. 2000; Hendricks et al. 2001; Keirle 2002) as well as in the visitor behavioural studies, particularly with illegal activities (Wood et al. 2006; Park et al. 2008).

The observation results were recorded in dedicated forms (available by email from the authors). The forms were completed for both persons using the park trails correctly and for those who wandered off the established trails. The reasons for walking off-trail were categorized as: 1) technical - including walking around obstacles and difficult spots on the trail, bypassing and overtaking other tourists either standing or moving more slowly on the trail, and also leaving the trail in connection with the need to relieve themselves; 2) volitional - involving rest periods beyond the trail, taking photographs, and other activities (e.g. observing wildlife, admiring the landscape, etc.).

Also recorded in the forms were the direction of movement of visitors (up or down), the age group (children, youths, young adults, older adults) and the manner of visiting the park (on their own or with a professional guide). The observations were conducted on working days and holidays, between 9 a.m. and 4 p.m., from May until September, in two series with a single observation lasting 10 minutes. In all, 2340 minutes were devoted to observations.

The assessment of techniques for managing the tourist trails and their surroundings, and estimates of negative environmental consequences resulting from off-trail walking, were made with the use of the field charting methodology proposed by Ewertowski and Tomczyk (Ewertowski \& Tomczyk 2007). This methodology was modified and adapted to the conditions in PNP (Kolasińska 2014). During the field work the following data were collected for each of the study areas:

1. Morphometric data of the trail, measured in three-meter intervals by wheel odometer, and laser rangefinder (Kolasińska 2014).

The data included:

- width of the trail determined at the time of its marking,

- width of zones trampled down (complete lack of vegetation) and zones with vegetation destroyed (plants trampled down, broken, leaves and flowers torn off) around the trail.

2. Other elements of impact caused by visitors walking off the trails - including the places where people relieved themselves, or single informal paths or their systems were developed. These elements were located on a map with the use of GPS receivers.

3. Ground cover - the types of habitats in the immediate vicinity of the trail were recorded, and divided into forest, non-forest and mixed habitats.

4. Comfort of walking on the trail surface (Guzikowa 1982) described using two categories: comfortable and uncomfortable trails.

5. Elements of the technical infrastructure preventing visitors from walking off trail - these included: protective boardwalks, barriers and kerbs.

6. Elements of tourist infrastructure - resting places with benches, information boards, signposts.

Spatial data items pertaining to the situation of study areas, informal trails and places where people relieved themselves were introduced into the GIS system based on the digital maps of the PNP.

The material collected was analysed statistically with the use of SAS JMP statistical software, ver. 9.0.2. The categorical type data were analysed using the $\chi^{2}$ (Pearson's Chi Square) test. The analysis of two categories, numerical and categorical data, was completed using the Wilcoxon test and the Kruskall-Wallis test. In the post-hoc analysis of the results calculated by both tests the Steel-Dwass test was used. The correlations between numerical variables were checked with the $\varrho$ (Spearman rank correlation) test. The detailed description of analyses and statistical tests used was presented in Kolasińska (2014).

\section{Results}

Characteristics of tourists walking off-trail

Of 12577 visitors who passed through the study areas during the time of the studies, 3685 (i. e. $29.4 \%$ ) walked off the trail. The proportion of visitors walking off-trail differed significantly between individual study areas $\left(\chi^{2}=737.55 ; \mathrm{p}<0.0001\right)$ and ranged from $9.8 \%$ on study area No. 2 to $51.3 \%$ on study area No. 6 (Figure 3).

Of those visitors (2394 persons) who rambled in organized groups with professional guides, 580 (24.2\%) walked off the trails. It is worth mentioning that signif-

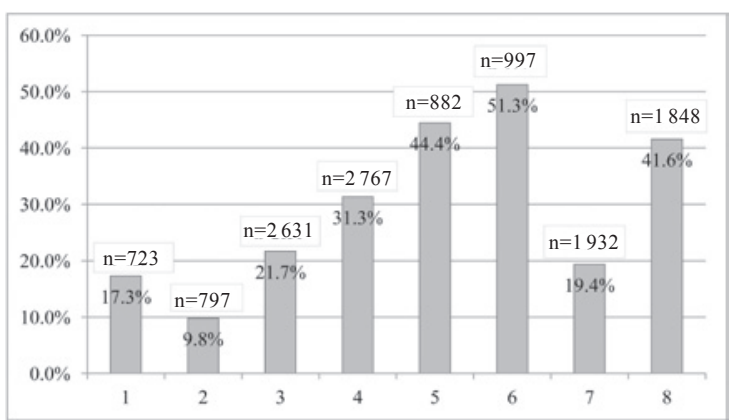

Figure 3 - The levels of off-trail walking in particular study areas. 


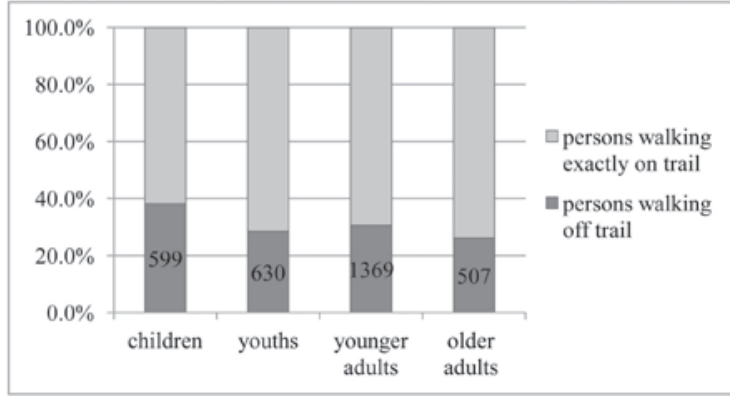

Figure 4 - Persons walking off-trail classified by age group.

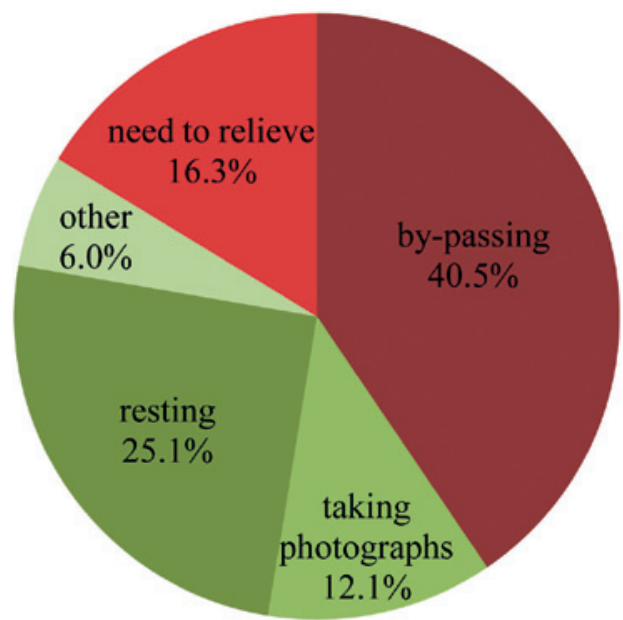

Figure 5 - Detailed reasons for walking off-trail. The technical reasons are marked in shades of red and the volitional reasons in shades of green.

icantly more - namely $30.5 \%\left(\chi^{2}=36.724 ; \mathrm{p}<0.0001\right)$ - of the tourists not using the services of guides walked off-trail. Within this group the smallest number of those walking off-trail $(26.2 \%)$ was found in the older adults group, whereas the most visitors frequently leaving the trail were those in the children category $38.2 \%$. The differences between the studied behaviour in the different age groups of visitors were statistically significant $\left(\chi^{2}=60.231 ; \mathrm{p}<0.0001\right)$ (Figure 4).

Of the 3685 recorded cases of persons walking off-trail, 56.8\% (2095) were for technical reasons; the remaining $43.2 \%$ (1590) cases were for volitional reasons. These differences were statistically significant $\left(\chi^{2}=69.225 ; p<0.0001\right)$ (Figure 5).

Despite the significantly higher frequency of persons in the children age category walking off-trail compared with those in the older adults category (cf. Figure 4), these groups frequently left the trails for volitional reasons, amounting to $51.9 \%$ and $50.1 \%$ respectively. On the other hand, young people and younger adults walked off-trail principally for technical reasons, amounting to $67.8 \%$ and $57.6 \%$ respectively $\left(\chi^{2}=59.502 ; \mathrm{p}<0.0001\right)$ (Figure 6).

A significant correlation was also found between the reasons for walking off-trail and the direction of movement by visitors $\left(\chi^{2}=587.343\right.$; $\left.\mathrm{p}<0.0001\right)$. The tourists ascending were leaving the trails more

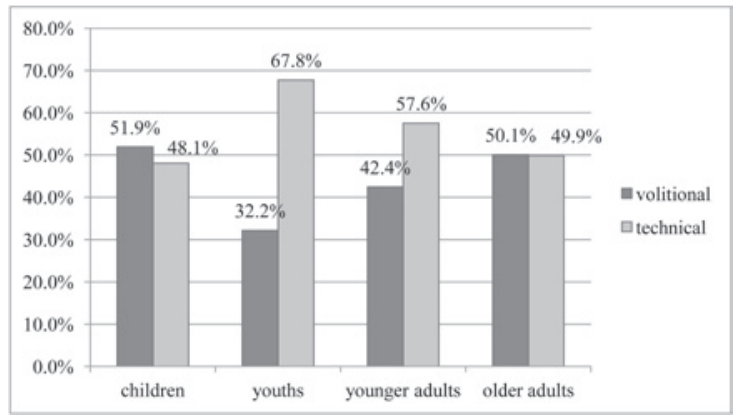

Figure 6 - The percentage of persons walking off-trail in individual age categories, in relation to their reasons.

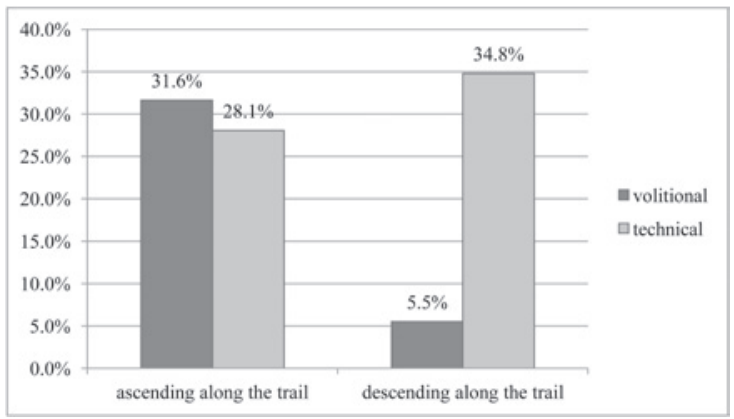

Figure 7 - Volitional and technical reasons for leaving trails depending on the direction of movement of tourists (ascending or descending).

frequently for volitional reasons than for technical reasons $(31.6 \%: 28.1 \%)$, whereas those descending were usually leaving the trails for technical reasons $(34.8 \%: 5.5 \%)$ (Figure 7).

The effect of path preparation on the number of tourists walking off-trail

The studies showed that the proportion of persons walking off-trail drops significantly when the trail has kerbs, barriers and places set for resting (Table 1). Walking off-trail is also significantly less frequent on trails with a comfortable surface (Table 1). Steps and culverts on the trail, as well as protective boardwalks and elements facilitating rest near the path did not significantly affect the proportion of tourists leaving the trails (Table 1).

In terms of walking off-trail for exclusively technical reasons, one can see that a significant decrease in the number of visitors walking off-trail is achieved by the presence of kerbs, places to rest and by the preparation of the trail surface (Table 2).

The study of the correlation between the trail width (Table 3) and the intensity of walking off-trail by visitors showed a negative correlation between walking off-trail and mean width $(\varrho=-0.2048 ; \mathrm{p}=0.0018)$ and minimum width $(\varrho=-0.3244 ; \mathrm{p}<0.0001)$. This means that the highest level of off-trail walking occurs on narrow trails.

It was also demonstrated that off-trail walking for technical reasons is negatively correlated with mean width $(\varrho=-0.3566 ; \mathrm{p}<0.0001)$ and minimum width 
Table 1 - Correlation between the proportion of tourists walking off-trail in relation to the total number of visitors and particular elements of trail infrastructure.

\begin{tabular}{|l|r|r|r|r|r|}
\hline \multirow{2}{*}{ Trail infrastructure } & \multicolumn{2}{|c|}{ Presence } & \multicolumn{2}{c|}{ Absence } & \multicolumn{1}{l|}{ Correlation } \\
\cline { 2 - 5 } & \multicolumn{1}{|c|}{$\mathbf{2 5} \mathbf{2 5} \mathbf{- 7 5} \%$} & \multicolumn{1}{c|}{ Me } & $\mathbf{2 5 \% - 7 5 \%}$ & \\
\hline Kerbs & 16.7 & $7.1-37,9$ & 27.8 & $8.9-47.6$ & $Z=2.10638 ; p=0.0352$ \\
\hline Culverts & 27.8 & $12.2-42.6$ & 18.1 & $2.7-50.0$ & $Z=1.6219 ; p=0.1030$ \\
\hline Steps & 18.3 & $5.8-39.8$ & 25.9 & $8.9-43.2$ & $Z=1.23113 ; p=0.2183$ \\
\hline Barriers & 3.1 & $0-12.0$ & 31.8 & $6.5-48.9$ & $Z=7.8362 ; p<0.0001$ \\
\hline Protective wooden gratings & 18.2 & $5.8-39.8$ & 25.9 & $8.9-43.2$ & $Z=1.05784 . p=0.2901$ \\
\hline Designated places to stop & 7.8 & $0-30$ & 27.8 & $12.2-44.3$ & $Z=3.75914 p=0.0002$ \\
\hline Elements to facilitate resting & 21.0 & $9.8-35.2$ & 28.8 & $7.2-50.6$ & $Z=1.44325 ; p=0.1487$ \\
\hline 'Comfortable' trail & 10.8 & $0-27.9$ & 38.5 & $16.9-52.6$ & $Z=7.06311 ; p<0.0001$ \\
\hline
\end{tabular}

Table 2 - Correlation between the proportion of visitors walking off-trail for technical reasons and particular elements of trail infrastructure.

\begin{tabular}{|l|r|r|r|r|r|}
\hline \multirow{2}{*}{ Trail infrastructure } & \multicolumn{2}{|c|}{ Presence } & \multicolumn{2}{c|}{ Absence } & \multicolumn{1}{l}{ Correlation } \\
\cline { 2 - 5 } & $\mathbf{M e}$ & $\mathbf{2 5 \% - 7 5 \%}$ & \multicolumn{1}{c|}{ Me } & $\mathbf{2 5 \% - 7 5 \%}$ & \\
\hline Kerbs & 0 & $0-75$ & 82.3 & $0-100$ & $Z=4.09179 ; p<0.0001$ \\
\hline Culverts & 21.2 & $0-100$ & 78.8 & $0-100$ & $Z=1.38716 ; p=0.1654$ \\
\hline Steps & 70 & $16.7-100$ & 21.4 & $0-100$ & $Z=0.9966 ; p=0.3190$ \\
\hline Barriers & 22.7 & $0-99.7$ & 51.9 & $0-100$ & $Z=0.75659 ; p=0.4493$ \\
\hline Protective wooden gratings & 70.0 & $16.7-100$ & 21.4 & $0-100$ & $Z=0.99661 ; p=0.3190$ \\
\hline Designated places to stop & 45.0 & $0-88.1$ & 45.0 & $0-100$ & $Z=0.59608 ; p=0.5511$ \\
\hline Elements to facilitate resting & 0 & $0-41.0$ & 100 & $66.6-100$ & $Z=9.5838 ; p<0.0001$ \\
\hline 'Comfortable' trail & 0 & $0-38.6$ & 90.5 & $0-100$ & $Z=5.58626 ; p<0.0001$ \\
\hline
\end{tabular}

$(\varrho=-0.5416 ; \mathrm{p}<0.0001)$ of a trail. It means that walking off-trail is more likely on those sections of trails where the width is narrow. Comparing correlation coefficients indicated the lesser importance of mean width compared with minimum width $(\mathrm{Z}=2.31$; $\mathrm{p}=0.0104)$.

Natural and environmental impact of visitors walking off-trail

The studies demonstrated significant differences between particular study areas depending on both the trampled zone $(\mathrm{H}=82.7561 ; \mathrm{df}=7 ; \mathrm{p}<0.0001)$, and the zone with damaged vegetation $(\mathrm{H}=65.5274$; df $=7 ; \mathrm{p}<0.0001$ ) (Table 4).

Another statistically significant correlation was found between the type of habitat surrounding a trail and the size of the damaged surface $(H=37.4932$; $\mathrm{df}=2 ; \mathrm{p}<0.0001)$. In forest areas, the width of a tram-

Table 3 - Parameters of trail width distribution within the study areas.

\begin{tabular}{|l|r|r|r|}
\hline $\begin{array}{l}\text { Study area } \\
\text { No. }\end{array}$ & $\begin{array}{l}\text { Mean width } \\
\text { of trail }(\mathbf{c m})\end{array}$ & $\begin{array}{l}\text { Minimum width } \\
\text { of trail } \mathbf{( c m})\end{array}$ & $\begin{array}{l}\text { Maximum width } \\
\text { of trail }(\mathbf{c m})\end{array}$ \\
\hline 1 & 338.1 & 256 & 452 \\
\hline 2 & 140.3 & 106 & 250 \\
\hline 3 & 220.5 & 180 & 281 \\
\hline 4 & 252.9 & 225 & 327 \\
\hline 5 & 152.8 & 125 & 236 \\
\hline 6 & 229.0 & 170 & 251 \\
\hline 7 & 332.6 & 227 & 513 \\
\hline 8 & 205.0 & 177 & 278 \\
\hline
\end{tabular}

pled zone (complete lack of vegetation) is significantly greater than in mixed $(\mathrm{Z}=5.35021 ; \mathrm{p}<0.0001)$ and non-forest habitats $(Z=5.35331 ; \mathrm{p}<0.0001)$. However, the difference was not significant $(Z=0.06565$; $\mathrm{p}=0.9976)$ between the mixed and non-forest habitats.

The same regularity was found in zones with damaged vegetation $(H=154.7565 ; \mathrm{df}=2 ; \mathrm{p}<0.0001)$.

The studies found (Spearman rank correlation test) a significant correlation between the width of the zone without ground cover and the intensity of tourist traffic $(\varrho=-0.1374 ; \mathrm{p}=0.0361)$ and the percentage of people walking off-trail $(\varrho=0.1287 ; p=0.0498)$. It was also shown that the width of the zone with damaged vegetation depended significantly on the intensity of visitor traffic $(\varrho=0.1896 ; p=0.0050)$ and on the percentage of people walking off-trail $(\varrho=0.1514$; $\mathrm{p}=0.0261)$.

Inventorying the irregular paths and places of defecation showed that irregular paths occurred near the study areas. Their combined length was $242 \mathrm{~m}$ or $63.0 \%$ of the total length of the studied sections of trails. The places where visitors defecated regularly were noticed near three study areas. Figure 8 presents the inventoried irregular paths and the places of defecation occurring in study area No. 5 .

\section{Discussion and conclusions}

Mass tourism in protected areas is a widespread phenomenon (Nianyong \& Zhuge 2001; Deng et al. 2003; Kalisch \& Klaphake 2007; Park et al. 2008; Par- 
Table 4 - Result of measurements of mean widths of damaged zones around the trails in the study areas.

\begin{tabular}{|r|r|r|r|r|r|}
\hline $\begin{array}{l}\text { Study area } \\
\text { No. }\end{array}$ & $\begin{array}{l}\text { Width of trampled down zone } \\
\text { on both sides of trail } \mathbf{( c m})\end{array}$ & $\begin{array}{l}\text { Standard de- } \\
\text { viation (SD) }\end{array}$ & $\begin{array}{l}\text { Width of the zone with damaged vege- } \\
\text { tation on both sides of the trail } \mathbf{( c m )}\end{array}$ & $\begin{array}{l}\text { Standard de- } \\
\text { viation (SD) }\end{array}$ \\
\hline 1 & 55.0 & 87.5 & 45.5 & 80.9 \\
\hline 2 & 170.5 & 183.6 & 332.4 & 447.3 \\
\hline 3 & 139.4 & 93.5 & 0 & 0 \\
\hline 4 & 4.3 & 15.0 & 72.7 & 147.3 \\
\hline 5 & 44.8 & 53.7 & 215.1 & 109.1 \\
\hline 6 & 125.5 & 123.2 & 207.9 \\
\hline 7 & 0 & 0 & 88.6 & 0 & 0 \\
\hline 8 & 83.3 & & & 0 \\
\hline
\end{tabular}

tyka 2010b) and the dynamics of tourism development involves a number of adverse effects resulting, for instance, in less comfortable tourists' visits and in increased threats to areas of high natural value immediately adjacent to tourist trails (Moore et al. 2012). Despite a number of actions undertaken by the natural parks' services, the deterioration in comfort levels for visitors and the increase in the threats to naturerelated values are still progressing (Monz et al. 2010; Olive \& Marion 2009; Pickering et al. 2010; Manning 2011). It is, however, worth noting that it is not the total number of visitors, but only the number of those who walk off the trail which influence the degree of the negative impact on nature and the environment in protected areas. Even though the phenomenon of walking off-trail is of essential importance, studies tracking this issue in national parks are rarely attempted. The probable reason for this is that it takes a lot of time and effort (Park et al. 2008). Still, even these sporadic research projects reveal how great the differences in visitors' behaviour can be as a result of various forms of tourist movement management, as well as between various protected areas.

An experiment conducted on Cadillac Mountain in Acadia National Park (Park et al. 2008) showed that, in the case of no action by the park's services, walking off-trail involved as many as $73.7 \%$ visitors (control). After applying the most effective method of visitor treatment this value dropped to $24.2 \%$. A similar phenomenon was also observed in PNP. The section of trail situated in study area No. 8 was repaired after the study (e.g. widening the trail, improving the quality of its surface, prevention measures such as a boardwalk along the trail), thereby markedly improving the comfort of visitors moving along the trail. A comparison of the proportion of visitors walking off-trail before $(41.6 \%)$ and after $(2.6 \%)$ the afore mentioned repairs indicates a major drop in the level of infringements (Witkowski et al. 2013).

The studies conducted in several national parks as well as in a nature reserve in southern Poland (Witkowski et al. 2010) also report significant differences between particular areas. In Ojców National Park (Kraków-Częstochowa Upland), on average 8.7\% of tourists walked off the marked trails, in Wawóz Homole Nature Reserve (Carpathians) the propor- tion amounted to $20.0 \%$ (Gmyrek-Gołąb et al. 2005), whereas the proportion found in the present study in PNP was 29.4\%. The above data indicate the need to intensify studies on the percentage of visitors who abandon the trails, compared with the total numbers of visitors, because it is only the actions of the former that result in damage to the natural environment of protected areas.

An important issue to be discussed are the reasons for which people leave the trails. Although the technical reasons for walking off-trail can be broadly understood (Root \& Knapik 1972; Bryan 1977), the volitional reasons reflect the differences between levels of knowledge, morality or experience among visitors (Symmonds et al. 2000; Park et al. 2008; Moore et al. 2012). The observations conducted in PNP confirmed those obtained in the Cadillac Mts. (Park et al. 2008); namely, that the study group most often leaving the paths are children. But taking into account only the volitional reasons, it transpires that high levels of offtrail walking were found in two groups: children and older adults (Figure 6). Of the two principal reasons for this, the technical reasons dominated (56.8\%). It may be assumed as highly likely that these resulted from the trail being badly managed or inadequate measures being taken to prevent off-trail wanderings. The analysis of the effects exerted by various elements of trail management on off-trail walking indicated that this hypothesis was well supported. Features of trails which markedly reduce the proportion of persons leaving the trails include kerbs, barriers, designated places to rest and convenient surfaces. The minimum width of trails is yet another essential element.

Damage exerted around the trails is the consequence of walking off-trail, which was widely documented in many national parks (Guzikowa 1982; Hammitt \& Cole 1998; Deng et al. 2003; Monz et al. 2010; Pickering et al. 2010). In PNP it was found that the widths of trampled zones and damaged vegetation zones depend on the number and percentage of people walking off-trail. The informal trails commonly observed in national parks (Bacon et al. 2006; Kim \& Daigle 2011; Leung et al. 2011; Wimpey \& Marion 2011; Walden-Schreiner \& Leung 2013) were also recorded in the studies within PNP, where they constituted $63.0 \%$ of the length of the studied sections of trails. 


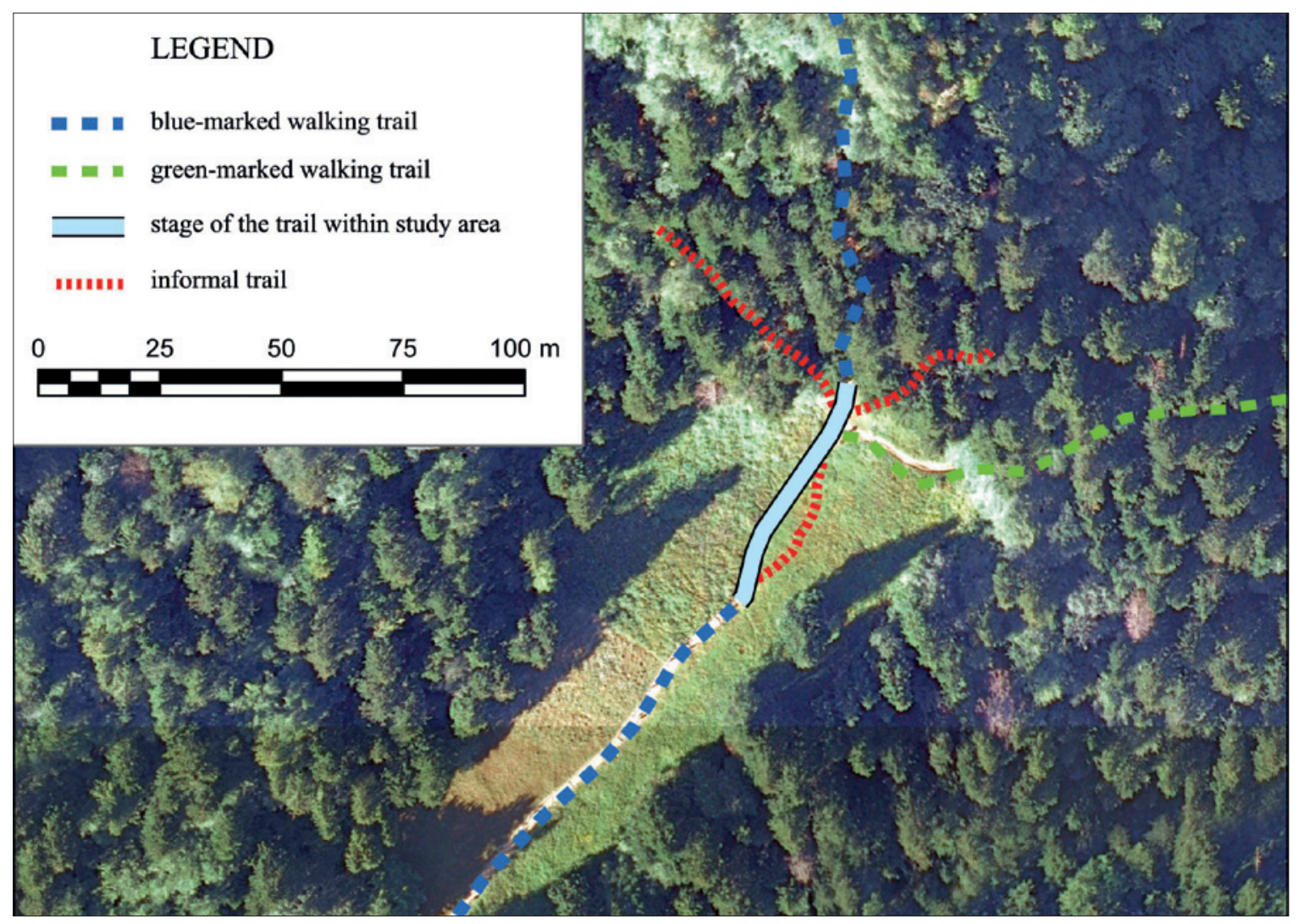

Figure 8-Distribution of inventoried irregularpaths and places where people relieved themselves within study area No. 5 (Kolasinskea 2014).

\section{Conclusions}

1. Studies on off-trail walking are not often attempted in national parks, although the numbers and proportions of tourists leaving the trails differ significantly as a result of applying various measures to protect the vicinity of trails against trespassing. Significant differences are also noted between particular protected areas. Such results point to the need for undertaking similar studies in other national parks.

2. The tourists walking off-trail are markedly rarer among those who visit the park in groups led by professional guides than among the other visitors. Children wander off the trail more often than young people and adults.

3. Of the reasons for walking off-trail, the technical reasons dominate over volitional ones. It was found, nevertheless, that visitors in two age categories (children and older adults) are walking off trails more often for volitional reasons than youths and younger adults.

4. The analysis of technical management of the trail and its surroundings showed that factors such as kerbs, barriers, designated places for rest and convenient trail surfaces are of considerable importance in terms of reducing the occurrence of offtrail walking.

5. The levels of off-trail walking significantly affects the spatial dimensions of damage such as: trampled zones and zones with damaged vegetation around the trail. Leaving the trails is also a direct cause of the emergence of informal trails, whose length on the studied areas constituted $63.0 \%$ of the total length of the studied trail sections.

6. Pieniny Mts. National Park is overloaded with tourists. This does not, however, exempt the park authorities from the obligation to take action to restrict visitors from leaving the trails, nor from the duty to properly care for the condition and quality of marked trails. The presented study confirms the observations known from professional publications that proper trail management reduces the level of off-trail walking, which results in a significant reduction in the degradation of nature and the environment in the park.

\section{Acknowledgements}

The authors wish to thank the management and staff of PNP for enabling the studies and providing the necessary information.

This scientific study was financed in 2010-2013 from the scientific funds for science as a research project N N305 097739. 


\section{References}

Adamski, P., A. Kolasińska \& Z. Witkowski 2013. Co wynika z badań nielegalnej dyspersji w parkach narodowych? In: Cybula, P. (eds.), Prawne aspekty bezpieczeństwa w górach - turystyka. rekreacja, sport. 111121. Cracow.

Bacon, J., J. Roche, C. Elliot \& N. Nicolas 2006. VERP: putting principles into practice in Yosemite National Park. George Wright Forum 23: 73-83.

Bazyly, J., J. Gulińska \& K. Kolanko 2003. Degradacja środowiska przyrodniczego szlaków turystycznych i ich najbliższego otoczenia w Wolińskim Parku Narodowym. In: Kostrzewski, A. (eds.), Wolinski Park Narodowy. Środowisko prayrodnicze. Ksz̧taltowanie i ochrona: 115-118. Poznań.

Bryan, R.B. 1977 The influence of soil properties on degradation of mountain hiking trails at Gro "velsjo" $n$. Geografiska Annaler Series A Physical Geography 59: 49-65.

Buckley, R. 1999. Tools and indicators for managing tourism in parks. Annals of Tourism Research 26 (1): 207-210.

Budruk, M. \& R.E. Manning 2006. Indicators and standards of quality at an urban-proximate park: Litter and graffiti at Boston Harbor Islands National Recreation Area. Journal of Park and Recreation Administration 24 (3): 1-23.

Bushell, R., R. Staiff \& P.F.J. Eagles 2007. Tourism and Protected Areas: Benefits Beyond Boundaries. In: Bushell, R. \& P. Eagles (eds.), Tourism and Protected Areas - The $V^{\text {th }} I U C N$ World Parks Congress: 1-11.

Celichowski, A. 1977. Studium Chłonności turystycznej. In: Plan ogólny pržestrzennego zagospodarowania Pienińskiego Parku Narodowego. Prace studialne i problemowe. iprolas, Warszawa. Maszynopis dostępny w Bibliotece Pienińskiego Parku Narodowego.

Cole, D.N. 2004. Impacts of hiking and camping on soils and vegetation: a review. Environmental impacts of ecotourism 41 (60): 41-58.

Deng, J., S. Qiang, G.J Walker \& Y. Zhang 2003. Assessment on and Perception of Visitors' Environmental Impacts of Nature Tourism: A Case Study of Zhangjiajie National Forest Park, China. Journal of sustainable tourism 11 (6): 529-547.

Dudley, N. (eds) 2008. Guidelines for Applying Protected Area Management Categories. Gland, Switzerland: IUCN: 86.

Dziadoń, J., J. Kosiniak, J. Jasiński, J. Stankiewicz \& M. Gruszeczka 2006. Informacja o wynikach kontroli. Funkcionowanie parków narodowych w zakeresie zachowania, zrównoważonego usytteowania oraz odnawiania zasobów przyrody. Najwyższa Izba Kontroli, Delegatura w Krakowie, Kraków.

Eagles, P.F.J. \& S.F. McCool 2002. Tourism services and infrastructure. In: Eagles, P.F.J. \& S.F. McCool (eds.), Tourism in national parks and protected areas. Planning and management: 171-186. Wallingford.
Ewertowski, M. \& A. Tomczyk 2007. Ocena stanu środowiska geograficznego szlaków turystycznych wykorzystanie GIS do integracji i analizy danych terenowych i kartograficznych. Przeglad Geograficzny 79 (2): 271-295.

Freimund, W.A. \& D.N. Cole 2001. Use Density, Visitor Experience, and Limiting Recreational Use in Wilderness: Progress to Date and Research Needs. USDA Forest Service Proceedings RMRS-P-20: 3-8.

Gmyrek-Gołąb, K., K. Krauz, M. Labaj, A. Mroczka, A. Tadel \& Z. Witkowski 2005. Tourist dispersion around a trail in „Wąwóz Homole” (Homole Gorge) nature reserve. Nature Conservation 61: 61-64.

Guzikowa, M. 1982. Wpływ pieszego ruchu turystycznego na szatę roślinną Pienińskiego Parku Narodowego (wybrane zagadnienia ze szczególnym uwzględnieniem skutków wydeptywania). Studia Naturae Seria A 22: 227-241.

Hammitt, W. E. \& D.N Cole 1998. Wildland recreation: ecology and management. New York.

Hendee, J.C., G.H Stankey \& R.C. Lucas 1990. Wilderness Management. Colorado.

Hendricks, W.W., R.H Ramthun \& D.J. Chavez 2001. The effects of persuasive message source and content on mountain bicyclists adherence to trail etiquette guidelines. Journal of Park and Recreation Administration 19 (3): 38-61.

Kalisch, D. \& A. Klaphake 2007. Visitors' satisfaction and perception of crowding in a German National Park: a case study on the island of Hallig Hooge. Forest Snow And Landscape Research 81: 109-122.

Kaźmierczakowa, R. 2004. Łąki, pastwiska i zbiorowiska siedlisk wilgotnych Pienińskiego Parku Narodowego. Studia naturae 49: 195-251.

Keirle, I. 2002. Observation as a technique for establishing the use made of the wider countryside: a Welsh case study. In: Arnberger, A., C. Brandenburg \& A. Muhar (eds.), Proceedings: Monitoring and Management of Visitor Flows in Recreational and Protected Area: 40-45. Vienna.

Kim, M. \& J. Daigle 2011. Detecting vegetation cover change on the summit of Cadillac Mountain using multi-temporal remote sensing datasets: 1979, 2001, and 2007. Environmental Monitoring and Assessment 180: 63-75.

Kiszka, K. 2010. Antropologiczne i naturalne uszkodzenia szlaków turystycznych w Pieninach polskich i słowackich. Pieniny - Pryyroda i Człowiek 11: 157-169.

Kolasińska, A. 2014. Aktywność fizyczna w Pieninskim Parku Narodowym: postawy $i$ qachowania osób odwiedzajacych a konsekwencje prayrodnicze $i$ środowiskowe. Praca doktorska. AWF Kraków. (unpublished).

Kuo, I. 2002. The effectiveness of environmental interpretation at resource - sensitive tourism destinations. International Journal of Tourism Research 4 (2): 87-101.

Leung, Y.F., J.L. Marion \& T.A. Farrell 2001. The role of recreation ecology in sustainable tourism and ecotourism. In: McCool, S.F. \& R.N. Moisey (eds.), 
Tourism, recreation and sustainability: Linking culture and the environment: 21-39. Wallingford.

Leung Y.F., T. Newburger, M. Jones, B. Kuhn \& B. Woidersk 2011. Developing a Monitoring Protocol for Visitor-Created Informal Trails in Yosemite National Park. US A Environmental Management 47: 93-106.

Lynn, N. \& R. Brown 2003. Effects of recreational use impacts on hiking experiences in natural areas. Landscape and Urban Planning 64: 77-87.

Manning, R.E. 2011. Studies in outdoor recreation: Search and research for satisfaction.

Manning, R.E. \& L.E. Anderson 2012. Managing outdoor recreation - Case studies in the national parks. Oxfordshire.

Manson, P. 2005. Visitor Management in Protected Areas: From 'Hard' to 'Soft' Approaches? Current Issues in Tourism 8: 181-194.

Mappes, H.A. 2007. National Parks: For Use and "Enjoyment" or for "Preservation"? and the Role of the National Park Service Management Policies in That Determination. Iowa Law Review 92: 601-636.

McCool, S.F. 2009. Constructing partnerships for protected area tourism planning in an era of change and messiness. Journal of Sustainable Tourism 17 (2): 133-148.

Monz, C.A., D.N. Cole, Y.-F. Leung, \& J.L. Marion 2010. Sustaining visitor use in protected areas: Future opportunities in recreation ecology research based on the USA experience. Environmental Management 45: 551-562.

Moore, R.L., Y.F. Leung, C. Matisoff, C. Dorwart \& A. Parker 2012. Understanding users perceptions of trail resource impacts and how they affect experiences: An integrated approach. Landscape and Urban Planning 107 (4): 343-350.

Newsome, D., S.A. Moore \& K. Dowling 2012. Natural area tourism: Ecology, impacts and management. Aspect of Tourism 58.

Nianyong, H. \& R. Zhuge 2001. Ecotourism in China's nature reserves: Opportunities and challenges. Journal of Sustainable Tourism 9 (3): 228-242.

Olive, N.D. \& J.L. Marion 2009. The influence of use-related, environmental, and managerial factors on soil loss from recreational trails. Journal of Environmental Management 90 (3): 1483-1493.

Orams, M.B. 1996. Using interpretation to manage nature-based tourism. Journal of Sustainable Tourism 4 (2): 81-93.

Poleno, Z. 1988. Wpływ masowej turystyki na roślinność i glebę. In: Olaczek, R. (eds.), Zasoby glebowe i roślinne - usytkowanie, zagrożenie, ochrona. Warszawa.

Park, L.O., R.E. Manning, J.L. Marion, S.R. Lawson \& Ch. Jacobi 2008. Managing Visitor Impacts in Parks: A Multi-Method Study of the Effectiveness of Alternative Management Practices. Journal of Park and Recreation Administration 26 (1): 97-121.

Partyka, J. 2010a. Udostępnianie turystyczne parków narodowych w Polsce a krajobraz. Prace Komisji Krajobrazu Kulturowego 14: 252-263.
Partyka, J. 2010b. Ruch turystyczny w Polskich Parkach Narodowych. Folia Turistica 22: 9-23.

Pickering, C.M., W. Hill, D. Newsome \& Y.F. Leung 2010. Comparing hiking, mountain biking and horse riding impacts on vegetation and soils in Australia and the United States of America. Journal of Environmental Management 91: 551-562.

Razowski, J. 2000. Charakterystyka flory i fauny Pienin. In: Razowski, J. (eds.), Flora i Fauna Pienin-Monografie Pienińskie 1: 11-21.

Root, J.D. \& L.J. Knapik 1972. Trail conditions along a portion of the Great Divide Trail Route, Alberta and British Columbia Rocky Mountains. Report 73-25. Research Council of Alberta, Edmonton, Alberta.

Symmonds, M.C., W.E. Hammitt \& V.L Quisenberry 2000. Managing Recreational Trail Environments for Mountain Bike User Preferences. Environmental Management 25 (5): 549-564.

Walden-Schreiner, Ch. \& Y.F. Leung 2013. Spatially Characterizing Visitor Use and Its Association with Informal Trails in Yosemite Valley Meadows. Environmental Management 52: 163-178.

Warcholik, W., K. Majewski \& K. Kiszka 2010. Ruch turystyczny w Pienińskim Parku Narodowym. Pieniny - Prayroda i całowiek 11: 149-156.

Watson, A.E., D.N. Cole, D.L. Turner \& P.S. Reynolds 2000. Wilderness recreation use estimation: A handbook of methods and systems. General Technical Report RMRS-GTR-56. Ogden, UT: USDA Forest Service, Rocky Mountain Research Station.

Wimpey, J.\& J.L. Marion 2011. A spatial exploration of informal trail networks within Great Falls Park, VA. Journal of Environmental Management 92: 1012-1022.

Witkowska-Żuk, L. 2000. Roślinność leśna w warunkach presji turystycznej. Sylwan 11: 5-22.

Witkowski, Z. 2003. Fauna Pienińskiego Parku Narodowego, jej zagrożenia i ochrona. Pieniny Pryyroda $i$ Catowiek 8: 63-82.

Witkowski, Z., A. Mroczka, P. Adamski, M. Bielański \& A. Kolasińska 2010. Nielegalna dyspersja turystów - problem parków narodowych i rezerwatów przyrody w Polsce. Folia Turistica 22: 35-65.

Witkowski, Z., A. Kolasińska \& P. Adamski 2013. Dyspersja turystów wokół szlaków na obszarze Pienińskiego Parku Narodowego oraz możliwości jej ograniczenia. In: Przewodnik stowacko-polskiej sesji posterowej „Badania naukowe w Pieninach 2013”: 37. Krościenko nad Dunajcem.

Wood, K.T., S.R. Lawson \& J.L. Marion 2006. Assessing Recreation Impacts to Cliffs in Shenandoah National Park: Integrating Visitor Observation with Trail and Recreation Site Measurements. Journal of Park and Recreation Administration 25 (4): 86-110.

Zarzycki, K. 1982. Przyroda Pienin w obliczu zmian. Studia Naturae seria B 30: 1-578. 


\section{Authors}

\section{Anna Kolasińska}

is a doctoral student at the Academy of Physical Education in Kraków. Her scientific interests focus on the issues of tourist management of protected areas, as well as the issues of awareness and ecological education of tourists. 31-571 Kraków, al. Jana Pawa II 78, Poland. Email: a.kolasinska@tlen.pl

Dr Paweł Adamski

Researcher at the Institute of Nature Conservation PAS. Specializes in the implementation of population and behavioural ecology in nature conservation practices, also interested in the environmental impact of tourism and recreation. 31-120 Kraków, al. Mickiewicza 33, Poland. Email: adamski@iop.krakow.pl

\section{Prof. Dr Zbigniew Witkowski}

Head of Department of Environmental Sciences. Author of over 270 publications on nature conser- vation and tourism, interested in the management of tourism in the context of nature conservation in protected areas. 31-571 Kraków, al. Jana Pawa II 78, Poland. Email: zbigniew.witkowski@onet.eu

\section{Dr Szymon Ciapała}

Head of Ecology Faculty; Academy of Physical Education in Kraków. His scientific interests focus on issues of tourist impact on nature and methods of tree-ring dating as assessment of the touristic impact. 31-571 Kraków, al. Jana Pawła II 78, Poland. Email: szymon.ciapala@awf.krakow.pl

\section{Dr. Juraj Švajda}

Assistant at Matej Bel University in Banská Bystrica (Slovakia). His research interests focus on protected area management, including monitoring visitors in national parks. Tajovského 40, 97401 Banská Bystrica. Slovakia. Email: juraj.svajda@gmail.com 